Abant Tıp Dergisi

Araştırma Makalesi / Cilt 10 Sayı 2 Yıl 2021
Abant Medical Journal

Research Article / Volume 10 Issue 2 Year 2021

\title{
Atipik Yerleşimli Trombozlar ile 40 Yaş Altı Erişkin Hastalardaki Tipik Yerleşimli Trombozlarda Etyolojik Faktörler
}

\section{Evaluation Of the Etiological Factors of Atypically Located Thrombosis and Typical Thrombosis In Adults Under 40 Years of Age}

Ferhat BINGÖL ${ }^{1(D)}$, Ihsan SOLMAZ ${ }^{1(D)}$, Mehmet Orhan AYYILDIZ ${ }^{2}$ (D)

${ }^{1}$ Sağlık bilimleri üniversitesi Gazi Yaşargil Eğitim ve Araştırma Hastanesi İç Hastalıkları Kliniği, Diyarbakır, Türkiye

${ }^{2}$ Dicle Üniversitesi Tıp Fakültesi, Hematoloji Anabilim Dalı, Diyarbakır, Türkiye

\section{Öz}

GiRiş ve AMAÇ: Yerleşim yerine göre semptomlar oluşturan, antikoagülan ve prokoagülan dengenin kalıtsal veya edinsel nedenlerle bozulması ile ortaya çıkan trombozlar, önemli morbidite ve mortalite nedenidir. Bu çalışmada atipik yerleşimli ve genç (40 yaş ve altı) tromboz tanılı hastalarda etyolojik risk faktörlerini belirlemeyi amaçladık.

YÖNTEM ve GEREÇLER: Retrospektif yapılan çalışmamızda; 40 yaşın altındaki hastalarda görülen tipik yerleşimli trombozlar ve herhangi bir yaşta atipik lokalizasyonlu trombozu bulunan hastalar seçildi. Atipik trombozlu hastalarda öne çıkan etiyolojik risk faktörleri kalıtsal ve edinsel nedenler açısından tarandı. Trombozların lokalizasyonlarına göre öne çıkan risk faktörleri araştırıldı.

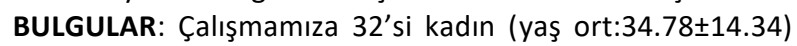

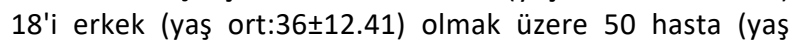
ort:35.22 \pm 13.56 ) dahil edildi. Hastaların 12 'si (\%24) 40 yaş üstü, 38'i (\%76) 40 yaş altı idi. Hastaların 7'sinde (\%14) oral kontraseptif (OKS) kullanımına bağlı, 6'sında (\%12) cerrahi sonrası, 1 'inde (\%2) gebelik esnasında, 1'inde (\%2) immobilzasyon nedeniyle, 2'sinde (\%4) hipertansiyona sekonder tromboz saptandı. MTHFR C677T, 8 (\%16) hastada homozigot, $4(\% 8)$ hastada heterozigot saptandı. MTHFR A1298C, 8 (\%16) hastada homozigot, 12 (\%24) hastada heterozigot ve MTHFR A1298C/C677T heterozigot birlikteliği 6 (\%12) hastada saptandı. Hastalardan 7'sinde (\%14) esansiyel trombositoz ve bu hastaların 4'ünde (\%8) JAK2 mutasyonu saptandı. Malignite öyküsü 1 (\%2), talasemi majör $1(\% 2)$ ve SLE $1(\% 2)$ hastada saptandı. Fak-V leiden mutasyonu 3 (\%6), Protein-S eksikliği 1 (\%2), Antitrombin III eksikliği 2 (\%4) hastada saptandı. Protrombin gen mutasyonu $2(\% 4)$ hastada heterozigot olarak tespit edildi. Lupus antikoagülanı $2(\% 4)$ hastada, fibrinojen düzeyi 1 (\%2) hastada yüksek saptandı. PAI-1 (4G/5G) gen polimorfizmi 5 (\%10) hastada saptandı. Tanı alan hastaların 31'inde (\%62) kalıtsal ve edinsel risk faktörleri bir arada saptandı. Hastaların 6'sında (\%12) herhangi bir kalıtsal veya edinsel risk faktörü saptanmadı.

TARTIŞMA ve SONUÇ: Atipik yerleşimli trombozlar ve 40 yaş altı erişkin hastalarda görülen tipik trombozlar kalıtsal ve edinsel etyolojik risk faktörlerinin bir arada saptanabildiği kompleks patolojik bir hastalıktır. Abdominal bölge trombozlarında etyolojik faktör olarak myeloproliferatif

\section{Abstract}

INTRODUCTION: Thrombosis, which causes symptoms depending on the location, and the deterioration of anticoagulant and procoagulant balance due to hereditary or acquired reasons, is an important cause of morbidity and mortality. In this study, we aimed to determine the etiological risk factors in patients with atypical localization and young (40 years and younger) patients diagnosed with thrombosis.

METHODS: In our retrospective study; All thrombosis seen in patients younger than 40 years and patients with atypical localized thrombosis at any age were selected. The prominent etiological risk factors in patients with atypical thrombosis were screened in terms of hereditary and acquired causes. Prominent risk factors according to the localization of thrombosis were investigated.

RESULTS: Fifty patients (mean age: $35.22 \pm 13.56$ ), 32 of whom were female (mean age: $34.78 \pm 14.34$ ) and 18 male (mean age: $36 \pm 12.41$ ), were included in our study. Twelve (24\%) of the patients were above 40 years old and 38 (76\%) were below 40 years old. In 7 of the patients (14\%) due to the use of oral contraceptives (OCS), 6 (12\%) after surgery, $1(2 \%)$ during pregnancy, 1 (2\%) due to immobilization, 2 (4\%), thrombosis secondary to hypertension was detected. MTHFR C677T was found to be homozygous in $8(16 \%)$ patients and heterozygous in $4(8 \%)$ patients. MTHFR A1298C was homozygous in $8(16 \%)$ patients, heterozygous in $12(24 \%)$ patients, and MTHFR A1298C / C677T heterozygous association was detected in $6(12 \%)$ patients. Essential thrombocytosis was found in $7(14 \%)$ of the patients and JAK2 mutation was found in $4(8 \%)$ of these patients. A history of malignancy was detected in $1(2 \%)$, thalassemia major $1(2 \%)$ and SLE 1 (2\%). Fak-V leiden mutation was detected in $3(6 \%)$ patients, Protein-S deficiency in $1(2 \%)$, and Antithrombin III deficiency in 2 (4\%) patients. Prothrombin gene mutation was detected as heterozygous in $2(4 \%)$ patients. The lupus anticoagulant was found to be high in $2(4 \%)$ patients, and the fibrinogen level in 1 (2\%) patient. PAI-1 (4G / 5G) gene polymorphism was detected in 5 (10\%) patients. Hereditary and acquired risk factors were found together in 31 (62\%) of the patients diagnosed. No hereditary or acquired risk factor was found in $6(12 \%)$ of the patients. 
hastalıkların değerlendirilmesi gerektiği ve kadınlarda OKS kullanımının altta yatan kalıtsal risk faktörlerinin varlığında tromboz riskini arttırdığı görüldü. Gebelik, lohusalık, OKS kullanımı gibi nedenlerden ötürü kadın cinsiyette daha fazla tromboz görüldüğü saptandı.
DISCUSSION and CONCLUSION: Atypical thrombosis and typical thrombosis seen in adults under 40 years of age is a complex pathological disease in which hereditary and acquired etiological risk factors can be determined together. It was observed that myeloproliferative diseases should be evaluated as an etiological factor in abdominal thrombosis and oral contraceptives (OCS) use in women increases the risk of thrombosis in the presence of underlying hereditary risk factors. It was found that female gender had more thrombosis due to reasons such as pregnancy, puerperium, and OCS use.

Keywords: Atypical thrombosis, thrombophilia, MTHFR, secondary thrombosis, hereditary and acquired etiology
Anahtar Kelimeler: Atipik tromboz, trombofili, MTHFR, sekonder tromboz, kalıtsal ve edinsel etyoloji

\section{GíRiş}

Trombofili (Thrombo-philia: trombozu sevme) tromboza eǧilim oluşturan tabloları tanımlamakta kullanılan bir terimdir. Tromboz gelişimi multifaktöriyeldir (1). Çok sayıda edinsel ve kalıtsal faktörün değişik mekanizmalarla tromboz oluşumuna neden olduğu bilinmektedir $(1,2)$. Tromboz multifaktöryel bir durumdur, tromboz, karmaşık bir patofizyolojik mekanizma yoluyla endojen antikoagülasyon ve hemostazda bir dengesizlik olduğunda ortaya çıkar. Tarihsel olarak, üç ortak faktör tromboza yatkınlık yaratır: 1- damar duvarının endotelyal tabakasında hasar; 2-hiperkoagülabilite ve 3- arteriyel veya venöz kan stazı. Bu üç faktör, "Virchow triadı" adıyla bilinir (3).

Tromboz toplumda sık görülen hastalık olup, önemli mortalite ve morbidite nedenlerinden biridir. Erişkinlerde insidansı yaklaşık \%1 iken, çocuklarda bu oran yılda 1/100.000 olarak belirtilmiştir (1). Tromboz etyolojisi karmaşık olup genelde birden fazla faktörü içerir. Genellikle herediter ve edinsel risk faktörlerinin etkileşimi sonucu ortaya çıkar $(1,2)$. Edinsel faktörler; cerrahi müdahale, obezite, cinsiyet, uzun süre hareketsiz kalmak, maligniteler, travma, nefrotik sendrom, myeloproliferatif hastalıklar, PNH, konjestif kalp yetmezliği, östrojen kullanımı, hamilelik ve lohusalık gibi doğrudan risk faktörleriyle bağlantılı ve yaşla artan bir insidans gösterir $(1,4)$.

Genetik hiperkoagulapatiden

genç yaşta trombozu olanlarda, ailesinde trombofili öyküsü olup, spontan, birden fazla ya da atipik bölgelerde trombozu olanlarda şüphenilmelidir. Genetik olarak hiperkoagulapatisi olanlarda çoğunlukla trombotik olaylar $45^{\prime}$ li yaşlardan önce ortaya çıkmaktadır. Her ne kadar kişilerde genetik hiperkoagulopati olsa da çoğunlukla kolaylaştırıcı bir durum olmadan tromboz meydana gelmemektedir. (5)

Kalıtsal trombofili nedenlerini genetik olarak taşıyan bireylerde tromboz riski artmakla birlikte yaşam boyu hiç trombotik atak geçirmemeleri de mümkündür. Bu durum, tek başına kalıtsal nedenlerin yeterli olmadığını, tromboz meydan gelmesinde bazı edinsel faktörlerin katkısı olduǧunu da göstermektedir. Kalıtsal trombofili tanısı için yapılacak testler oldukça zahmetlidir, pahalıdır ve uygun testler kullanılmazsa yanıltıcı sonuçlar elde edilebileceǧinden titizlikle seçilmelidir.

Tromboz için en sık görülen kalıtsal risk faktörleri olan faktör V Leiden ve protrombin G20210A gen mutasyonu venöz tromboembolim açısından yüksek risk taşırlar. Bu trombofili nedenleri, tekrarlayan venöz tromboemboli ataklarını artırmaktadır. Geriye kalan olguların çoğunda trombofili nedeni; protein $\mathrm{C}$, protein $\mathrm{S}$ ve antitrombin-III eksikliğidir. Diğer nedenler; Hiperhomosisteinemi: Sistatiyonin-beta sentetaz, metiyonin sentetaz ve metilen tetrahidrofolat redüktazın kalıtsal eksikliği Heparin kofaktör II eksikliği Plazminojen eksikliği 
Disfibrinojenemiler Faktör XII eksikliği Faktör VIII koagülan aktivitesinde artı̧̧ (1,6-8).

Çalışmamızda amacımız, atipik trombozlu hastalarda etyolojik risk faktörlerini belirlemek, tromboz yerleşim yerine göre öne çıkan etyolojik risk faktörlerini sınıflamak, birden fazla risk faktörü olan hastaları tekrarlayan trombozlar açısından uyarmak.

\section{GEREÇ ve YÖNTEMLER}

Çalışmaya 2014-2016 yılları arasında Dicle üniversitesi tıp fakültesi hastanesi hematoloji polikliniğine, tromboz tanısı almış ve etyolojik faktörler açısından konsülte edilmiş hastalar ile iç hastalıkları birimimizde kliniklerde takip edilen atipik yerleşimli ve genç yaşta (40 yaş ve altı) tromboz tanısı almış 50 (32K/18E) olgunun retrospektif analizi yapılmıştır. Çalışmaya dışlama kriteri olarak 16 yaş altı hastalar dahil edilmedi. Bu çalışma için üniversitenin medikal araştırma etik kuruluna başvuru yapılarak onay alınmıştır (proje numarası:362 onay tarihi:04.11.2015). Hastaların hastane kayıt sisteminden dosyalarına ve iletişim adreslerine ulaşıldı. Çalışmaya alınan hastaların tanıları genellikle görüntüleme yöntemleri ile konulmuştu. Serebral-sinüs ven trombozlu ve iskemik inme için; bilgisayarlı tomografi (BT), manyetik rezonans görüntüleme (MR), BT anjiyografi ve MR anjiyografi, derin ven trombozlu hastalar için; doppler ultrasonografi ile, Pulmoner tromboemboli hastaları; ventilasyon-perfüzyon sintigrafisi, torax tomografisi ve BT pulmoner anjiyografi ile, Portal, hepatik, splenik, mezenter, vena cava inferior trombozlu hastalar; hepatik doppler ultrasonografi, batın tomografi, BT anjiyografi ve $M R$ görüntülemesi ile juguler ven tromboz; doppler ultrasonografi ile üst extremite ven trombozu; doppler ultrasonografi ile retinal ven trombozlu hastalar için; göz dibi muayenesi ve FFA (ffa fundus fluorescein angiography) yöntemleri kullanılarak tanı konulmuştu. Tromboz etyolojisini saptamak için iletişime geçilen hastalardan tanı anında yaşı, cinsiyet, meslek, şikayetleri ek hastalık olup olmadığı, cerrahi operasyon öyküsü, ailede tromboz öyküsü, travma, immobilite, kanser öyküsü, sigara öyküsü, kadın hastalardan tekrarlayan düşük öyküsü, tanı esnasında gebelik öyküsü, oral kontraseptif kullanımı ve hipertansiyon, diyabet tanılarının olup olmadığı sorgulandı. Tanı anındaki ve kontrollerdeki ailesel ve edinsel trombofili açısından çalışılan; antitrombinIII, protein C, protein S, Aktive Protein C Rezistansı, faktör $\mathrm{V}$ leiden mutasyonu, Protrombin gen mutasyonu, PAi-1 gen mutasyonu, JAK2 mutasyonu, PNH klonu, , lupus antikoagülanı, antikardiolipin IgM-IgG, hemogram, fibrinojen, $d$ dimer düzeyleri hastaların hastane kayıt sistemindeki dosyalarından incelendi.

\section{İstatistik}

Çalışmada elde edilen sonuçların istatistiksel analizleri SPSS (statistical package for social scienses) Windows 18.0 programı kullanılarak yapıldı. Verilerin değerlendirilmesinde değişkenlerin frekans tabloları oluşturuldu. Sonuçlar ortalama \pm SD ve yüzde (\%) olarak verildi. Tanı gruplarına göre sayısal değişkenlerin ortalama olarak farklı olup olmadığı ANOVA testi ile test edildi. Kategorik değişkenler için de Kikare testi kullanıldı. $\mathrm{P}<0.05$ istatistiksel olarak anlamlı kabul edildi.

\section{BULGULAR}

Çalışmaya 32'si kadın (\%64) ve 18'i erkek (\%36) 50 hasta dahil edilmiştir. Kadınların yaş ortalaması; $34.78 \pm 14.34$, erkeklerin yaş ortalaması; $36 \pm 12.41$, tüm hastaların yaş ortalaması; $35.22 \pm 13.56$ ve kadın erkek oranı K/E: 1.7/1 bulundu. Çalışmaya alınan hastalardan 12 'si (\%24) 40 yaş üstü ve 38'sı (\%76) 40 yaş altı saptandı. 40 yaş üstü hastalardan 5 'i (\%10) erkek, 7'si (\%14) kadın, 40 yaş altı hastalardan 13'ü (\%26) erkek, 25'i (\%50) kadın olarak saptandı (Tablo 1).

Hastaların tanıları incelendiğinde; Abdominal trombozlar \% 36 (11K/7E) [ Portal ven trombozu 
\%14 (4K/3E), hepatik ven trombozu \% 10 (3K/2E), mezenter ven trombozu \% 4 (2K), portalmezenter ven trombozu $\% 4(1 \mathrm{~K} / 1 \mathrm{E})$, vena cava inferior trombozu \% 2 (1K), splenik ven trombozu $\% 2(1 \mathrm{~K})]$, derin ven tromboz $\% 20(8 \mathrm{~K} / 2 \mathrm{E})$, pulmoner tromboemboli \% $8(4 \mathrm{~K})$, iskemik inme $\% 10(2 \mathrm{~K} / 3 \mathrm{E})$, sinüs ven trombozu $\% 8(3 \mathrm{~K} / 1)$, retinal ven trombozu ve iskemik inme $\% 4$ (1K/1E), üst extremite venöz trombozu \% 2 (1E), juguler ven trombozu \% $2(1 \mathrm{~K})$, retinal ven trombozu \% 10 (3K/2E) olarak saptandı (Tablo 2).

Etyolojik Risk Faktörleri incelendiğinde; Tromboz tanılı hastalardan kadın hastaların 7'sinde (\%22) OKS kullanımı sonrası tromboz gelişmişti. Cerrahi sonrası 6 (\%12) hastada, gebelik esnasında 1 (\%2) hastada, immobilizasyon nedeniyle 1 (\%2) hastada tromboz saptandı. 2 (\%4) hastada hipertansiyon öyküsü mevcuttu. Hastaların 7 'sinde (\%14) esansiyel trombositoz saptandı ve bu hastaların 4 'ünde (\%8) JAK2 mutasyonu eşlik ediyordu.

Hastaların 1'inde (\%2) malignite öyküsü, 1'inde (\%2) talasemi major, 1'inde (\%2) SLE tanısı saptandı.

Faktör-V leiden mutasyonu 3 (\%6) hastada, protein-S eksikliği 1 (\%2) hastada Antitrombin III eksikliği 2 (\%4) hastada saptandı, Protrombin gen mutasyonu $2(\% 4)$ hastada heterozigot saptandı.

Lupus antikoagülanı ve antifosfolpid antikorları 2'şer (\%4) hastada, fibrinojen 1 (\%2) hastada yüksek saptandı. MTHFR C677T, 8 (\%16) hastada homozigot, 4 (\%8) hastada heterozigot saptandı. MTHFR A1298C, 8 (\%16) hastada homozigot, 12 (\%24) hastada heterozigot ve MTHFR A1298C/C677T heterozigot birlikteliği 6 (\%12) hastada saptandı. Aktive protein C Rezistansı, protein $\mathrm{C}$ eksikliği, $\mathrm{PNH}$, travma öyküsü, tüm hastalarda değerlendirildi, ancak hiçbir hastada saptanmadı. Tanı alan kadın hastalardan 13 (\%26) hastada düşük öyküsü saptandı (en fazla 2 düşük). Hastaların 31'inde (\%62) birden fazla risk faktörü bir arada saptandı. Hastaların 6'sında (\%12) herhangi bir kalıtsal ve edinsel risk faktörü saptanmadı (Tablo 3).

\section{TARTIŞMA}

Tromboz; vasküler sistemde kanın fizyolojik akışkanlığını engelleyen, hemostatik sistemde koagülasyon sistemi ile antikoagülan-fibrinolitik sistemin arasındaki dengenin edinsel veya kalıtsal nedenlerle bozulması sonucu ortaya çıkan patolojik bir durumdur. Arteriyel ve venöz sistemi tutabilir. Yerleştiği alana göre klinik oluşturur. Özellikle gençlerde görülen, nüks eden, atipik yerleşimli ve ailesel gözüken vakalar trombusun etyolojisinde genetik faktörlerin varlığını düşündürmüştür. Genetik risk faktörleri taşıyan bireylerde tromboz riski artmakla birlikte, herhangi bir trombotik atak geçirmemeleri de mümkündür. Bu durum kalıtsal nedenlerin tek başına yeterli olmadığını, kalıtsal nedenlere ilaveten bazı edinsel faktörlerin de katkısı olduğunu göstermektedir (7-10).

Çalışmamızda 50 atipik yerleşimli ve genç tromboz tanılı hastanın etyolojik risk faktörlerinin araştırılması sonucunda; hastaların \% 64'ü kadın ve $\% 36$ 'sı erkek cinsiyette (K/E:1.7/1) idi. Kalıtsal ve edinsel risk faktörleri 31 (\%62) hastada bir arada saptandı. Hastaların 6'sında (\%12) herhangi bir kalıtsal veya edinsel risk faktörü saptanmadı. OKS kullanımı sonrası tromboz özellikle serebral sinüs ve alt extremite trombozlarında öne çıkmaktaydı. Myeloproliferatif hastalıklardan esansiyel trombositoz, özellikle abdominal (hepatik, portal, mesenterik) bölge trobozlarında risk faktörü olarak dikkati çekmiştir. Cerrahi sonrası tromboz özellikle abdominal trombozlarda öne çıkan risk faktörü olarak saptandı. Edinsel risk faktörleri olarak; major cerrahi, immobilizasyon, gebelik, hipertansiyon, malignite, OKS kullanımı, kalıtsal risk faktörleri olarak; MTHFR gen mutasyonları, protrombin gen mutasyonu, PAI-1 (4G/5G) gen polimorfizmi, fak$\checkmark$ leiden mutasyonu, Antitrombinlll eksikliği ve protein-S eksikliği saptandı. MTHFR gen mutasyonları, PAI-1 (4G/5G) polimorfizmi ve fak$\checkmark$ leiden mutasyonu en fazla tespit ettiğimiz 
kalıtsal risk faktörleriydi. Yerleşim yerlerine göre öne çıkan kalıtsal risk faktörü saptanmadı. Romatolojik hastalıklardan şjögren sendromu ve SLE, yine hematolojik hastalıklardan Talasemi major de saptadığımı etyolojik risk faktörlerindendi.

Decous ve arkadaşlarının yaptığı prospektif venöz tromboeembolizmin epidemiyolojik çalışmasında vakaların üçte ikisi kadın olarak saptanmıştır (11). Bizim çalışmada da hastaların cinsiyet dağılımı K/E:1.7/1 olup, yapılan çalışma ile benzer bulundu.

Martinelli ve arkadaşlarının yaptığı derlemede VTE' nin en sık görülen genetik belirleyicileri olarak faktör V Leiden (\%20) ve protrombin mutasyonu (\%10) olarak saptanmıştır. Kalıtsal trombofili, VTE tanılı hastaların 1/3 ünde olup özellikle alt ekstremitedeki derin ven trombozunun etiyolojisinde önemli bir rol oynamaktadır. Kalıtsal koagülasyon bozuklukları dışında kanser, yakın zamanlı geçirilmiş cerrahi, travma, uzun süreli immobilizasyon, oral kontraseptif kullanımı veya hormon replasman tedavisi, hamilelik ve lohusalık gibi geçici durumların da VTE ile ilişkisi olduğu tanımlanmıştır (12). Venöz tromboembolizmin kalıtsal ve edinsel risk faktörleri arasındaki bir çok etkileşimden kaynaklanan kompleks bir rahatsızlık olduğunu biliyoruz. Bizim çalışmamızda da benzer olarak vakaların \%62 sinde kalıtsal ve edinsel risk faktörlerini bir arada saptadık. Hastalarda saptadığımız edinsel etyolojik risk faktörleri açısından da benzer sonuçlar elde ettik. Kalıtsal etyolojik risk faktörleri açısından sonuçlarımız; MTHFR C677T hom/het; \%16/\%20, MTHFR A1298C hom/het; $\% 16 / \% 36$, PAl-1 (4G/5G) gen polimorfizmi \%10, fak-V Leiden mutasyonu heterozigot \%6, protrombin gen mutasyonu heterozigot \%4, antitrombin III eksikliǧi \%4, protein-S eksikliǧi \%2 olarak saptadık.

MTHFR C677T polimorfizmi toplumda sık görülmektedir. Türkiye'de yapılan tarama çalışmaları toplumda homozigot C677T sıklığının $\% 5$, heterozigot sıklığının ise \%35 civarında olduğu saptanmıştır (13). Bizim çalışmamızda trombozlu hastalarda MTHFR homozigot C677T ve $A 1298 C$ sıklığının toplumun 3 katı kadar yüksek olduğu görüldü.

MTHFR C677T mutasyonlarının iskemik inme üzerine olan etkisini araştıran 900 hastayı içeren 24 çalışmanın yeraldığı bir meta-analizde, kontrollere göre inme geçiren hastaların, artan homosistein düzeylerine sahip olduğu belirlenmiştir (14). Alkanlı ve arkadaşlarının iskemik inme için genetik risk faktörlerinin araştırıldığı 82 iskemik inmeli hasta ve 92 kontrol grubuyla yaptıkları çalışmada; Trakya bölgesinde MTHFR A1298C gen polimorfizmin iskemik inme için genetik risk faktörü olduğu ve MTHFR C677T gen polimorfizminin ise diǧer sınıflandırılmayan alt grubu için risk faktörü olduğu iddia edilmiştir. Çelik ve arkadaşlarının 45 yaşın altında akut myokard infarktüsü tanısı almış 93 erkek ve 24 kadın hasta ile sağlıklı 56 erkek ve 51 kadın kontrol grubu ile yaptıkları çalışmada; erkek hastalarla kontrol grubu arasında heterozigot MTHFR mutasyonları arasında önemli fark olduǧunu saptamışlardır $(p<0.05)$ (15). Bizim çalışmamızda MTHFR gen mutasyonlarının tüm hastaların \%76'sında saptanması yüksek bir oran olup, daha spesifik ve daha fazla alt grupları analiz edilmiş hasta ve kontrol gruplarıyla yapılacak çalışmalara ihtiyaç vardır.

PAl-1 Plasminojenin plazmine dönüşümünde aktivatör görevi yapan doku plasminojen aktivatörü ve ürikinaz' I inhibe eder. PAI-1' in serum seviyeleri genetik faktörlerle ilişkili olup, yüksek serum düzeyleri, tromboza yatkınlık yaparak hipofibrinolitik durum oluşumuna katkıda bulunur (16). PAI-1 heterozigotluğu \%44.0, homozigotluğu \%24.0 oranında görülmüştür. (17). PAl-1 4G allel varlığının PAI-1 seviyesini artırdığı bilinmektedir. PAl-1 4 Guanozin/5 Guanozin (4G/5G) polimorfizminin VTE oluşumundaki ilişkisine dair pek çok çalışma vardır. Sonuçlar çalışmadan çalışmaya farklılık 
göstermektedir. VTE ve 4G/5G genotipi arasında ilişki olmadığını bildiren araştırmacılara ek olarak bu ilişkinin pozitif veya negatif yönde olduğunu bildiren araştırmacılar da bulunmaktadır (18-20). Bizim çalışmamızda PAI-1(4G/5G) gen polimorfizmi \%10 hastada saptandı tromboza olan etkisi için daha spesifik ve geniş çalışmalara intiyaç vardır.

Martinelli ve arkadaşlarının Serebral ven trombozlu 40 hasta ve derin ven trombozlu 80 hasta ile 120 kontrol grubunda OKS kullanımı ve genetik risk faktörleri üzerine yaptıkları çalışmada; serebral ven tromboz vakalarında alt ekstremite DVT hastalarında bulunanlardan daha yüksek veya benzer bir trombofili prevelans saptanmış (faktör-V Leiden için \%15-20). Geçici risk faktörleri arasında oral kontraseptif kullanımı, gebelik ve lohusalık (\%30-80) çok önemli bir role sahiptir. Çalışmaların çoǧunda kadınların erkeklere oranının yüksek olma nedeni olarak belirtilmiştir (21). De stefano ve arkadaşlarının yaptığı başka bir çalışmada, Polisitemia vera ve esansiyel trombositemi gibi myeloproliferatif hastalıkların seyri esnasında serebral ven ve sinüs ven trombozu (CVST) görülebilir $(22,23)$. Brujin ve arkadaşları ile martınelli ve arkadaşlarının yaptığı farklı çalışmalarda Östrojen-kombine oral kontraseptif kullanımının CVST için presipite edici bir risk faktörü olarak saptamışlar (24). Bizim çalışmamız ile özellikle; OKS kullanımı (CVT tanılı hastaların $\% 30 \mathrm{u}$ ) ve kadın cinsiyet hakimiyeti (K/E: 6/5) açısından benzerlik göstermektedir yine myeloproliferatif hastalıkların seyri esnasında CVST saptanması açısından bizim çalışmaya dahil ettiğimiz CVST- Iskemik inme tanılı hastaların \%10'unda saptanması açısından benzerlik göstermektedir.

Primignani ve arkadaşlarının portal ven trombozlu daha önceden karaciğer sirozu mevcut olmayan 60 hasta ile yaptıkları çalışmada, trombofili prevelansını genel olarak \%25 saptamışlar. De stefano ve arkadaşları, Hoekstra ve arkadaşları ile Valla ve arkadaşlarının yaptıkları çalışmalarda Portal ven trombozunun altta yatan en sık etyolojisi olarak siroz saptanmış olup Diǧer etyolojik risk faktörleri olarak ise; intraabdominal enfeksiyonlar, inflamasyon, malignite, künt travma, cerrahi ve Myeloproliferatif hastalıkların (MPN) vakaların dörtte birini oluşturduğu, portal ven trombozunun MPN'nin yaygın prezentasyon bölgelerinden olduğunu saptamışlardır. Yine Ziakas ve arkadaşlarının yaptığı çalışmada tüm PVT hastalarının JAK2 V617F mutasyonları açısından değerlendirilmesi gerektiği ve Paroksismal noktürnal hemoglobinüriyi $(\mathrm{PNH})$ de intraabdominal trombozisin önemli bir sebebi olarak belirtmişledir. Darwish Murad ve arkadaşlarının yaptığı çalışmada hepatik ven trombozlu hastaların birçoǧunda altta yatan protrombik bir rahatsızlık olduğu, yarısında myeloproliferatif bir hastalık saptandığı ve bunların \%30 unda JAK2 V617F mutasyonu olduğunu göstermişlerdir. Sakorafas ve arkadaşları çalışmalarında izole splenik ven trombozu etyolojisinde en sık sebep olarak pankreatik hastalıkları saptamışlar. Kumar ve arkadaşlarının yaptığı çalışmada mezenterik ven trombozunun mezenterik iskemilerin \%10'unu oluşturduğu, en sık sebepler arasında protrombotik durumlar, kanser, intraabdominal inflamasyon yada enfeksiyon, siroz ve cerrahi olduğu gösterilmiştir. (24-29). Bizim çalışmamız ile karşılaştırdığımızda abdominal (hepatik, portal, splenik, vena cava inferior, mesenterik) trombozlarda myeloproliferatif hastalıklar (esansiyel trombositoz; \%14) açısından benzer sonuçlar saptadık. Cerrahi ve malignite varlığı da abdominal trombozlarda etyolojik risk faktörü olarak saptadığımız benzer bulgulardı. Portal ven trombozunun en sık sebebi karaciğer sirozu olmasına karşın, bizim çalışmamızda hastalar karaciğer sirozu olmayan hasta populasyonundan seçilmişti. Hasta sayımızın az olması dolayısıyla daha fazla hasta gruplarıyla geniş çalışmalara intiyaç vardır.

Retinal ven öklüzyonu (RVO), VTE'nin nadir bölgeleri arasına dahil edilmemelidir, çünkü gerçek prevelansı bilinmemesine rağmen 
nispeten daha sık görülen bir hastalıktır. Prisco ve arkadaşalarının yaptığı çalışmada RVO, arteriyel hipertansiyon, diyabet mellitus, dislipidemi ve sistemik vaskulit gibi çeşitli sistematik hastalıkların genel bir komplikasyonu olarak bildirilmiş ve RVO etiyolojisindeki trombofilinin rolünün marjinal olduğu belirtilmiştir. 21 çalışma üzerinde yapılan meta-analizde vakaların \%64 ünde hipertansiyon, \%35'inde hiperlipidemi ve \%15'inde diyabet bulunmuştur. RVO büyük oranda yaşlılıkla ilgili bir durumdur, ancak direkt olarak ateroskleroz, endotelyal disfonksiyon, inflamasyon ya da koagülasyon aktivasyonu ölçümleriyle ilişkili deǧildir. RVO ile herediter trombofili arasında güçlü bir ilişki yoktur. Hayreh ve arkadaşlarının 26 çalışmadan derledikleri bir meta-analize göre sadece hiperhomosisteinemi ve anti- kardiolipin antikorları ile RVO arasında anlamlı ilişki bulunmuştur. Janssen ve arkadaşalarının yaptığı çalışmada fak-V leiden mutasyonu ile sınırda ilişki saptanmıştır (30). Çalışmamızda retinal ven trombozu olan 5 (\%10) hasta ve hem retinal hemde serebral ven trombozu olan 2 (\%4) hasta saptandı. Sadece retinal ven trombozu olan hastaların tümü 40 yaş altı hasta grubundan seçilmişti. Bizim çalışmamızda özellikle atipik olması açısından genç hastalar seçilmişti bu anlamda yapılan çalışmalarda saptanan yaşlı populasyonda daha sık saptanır tezine uymuyordu. Hasta sayımızın az olmasından dolayı daha geniş hasta populasyonu ile yapılacak çalışmalara ihtiyaç vardır.

\section{Sonuç;}

Atipik trombozların etyolojisinde tek başına kalıtsal ya da çevresel risk faktörleri etyolojik neden olmakla birlikte, bizim bu seçilmiş gruplarda yaptığımız çalışmada birden fazla etyolojik risk faktörünün birlikte olduğunu tespit ettik.

Yerleşim yerlerine göre risk faktörlerinin özellik gösterebildiği, örneğin abdominal (hepatik, portal, mezenterik) tromboz nedeniyle başvuran hastalarda myeloproliferatif hastalıkların
(Esansiyel trombositoz) öne çıkan bir risk faktörü olduğu saptandı.

MTHFR homozigot C677T ve A1298C gen mutasyonlarının atipik trombozlu hastalarda artmış oranda saptandığı görüldü. Atipik tromboz tanısı ile başvuran hastalarda kalıtsal etyolojik risk faktörlerinin saptanabileceği bu nedenle bu hasta gruplarında herediter risk faktörlerinin araştırılması gerektiği kanaatine varıldı.

Bilgilendirilmiş Onam: Katılımcılardan yazılı onam alınmıştır.

Çıkar Çatışması: Yazarlar çıkar çatışması beyan etmemişlerdir.

Finansal Destek: Yazarlar finansal destek beyan etmemişlerdir.

\section{KAYNAKLAR}

1. Rosendaal FR. Venous thrombosis: a multicausal disease. Lancet. 1999 Apr 3;353(9159):1167-73.

2. Lichtman M.A. BE, Kipps T.J., Seligsohn U., Kaushansky K., Prchal J.T. 7th ed, ed: McGraw-Hill Co.; 2005.

3. Bagot CN, Arya R. Virchow and his triad: a question of attribution. Br J Haematol. 2008 Oct;143(2):180-90.

4. Cushman M, Glynn RJ, Goldhaber SZ, Moll S, Bauer KA, Deitcher $\mathrm{S}$, et al. Hormonal factors and risk of recurrent venous thrombosis: the prevention of recurrent venous thromboembolism trial. J Thromb Haemost. 2006 Oct;4(10):2199-203.

5. Eichinger S, Minar E, Hirschl M, Bialonczyk C, Stain M, Mannhalter $C$, et al. The risk of early recurrent venous thromboembolism after oral anticoagulant therapy in patients with the G20210A transition in the prothrombin gene. Thromb Haemost 1999; 81(1): 1417

6. Lane DA, Mannucci PM, Bauer KA, Bertina RM, Bochkov NP, Boulyjenkov V, et al. Inherited thrombophilia: Part 2. Thromb Haemost. 1996 Dec;76(6):824-34.

7. Wu O, Robertson L, Twaddle S, Lowe G, Clark P, Walker I, et al. Screening for thrombophilia in high-risk situations: a meta-analysis and cost-effectiveness analysis. Br J Haematol. 2005 Oct;131(1):80-90.

8. Svensson PJ, Dahlback B. Resistance to activated protein $\mathrm{C}$ as a basis for venous thrombosis. N Engl J Med. 1994 Feb 24;330(8):517-22.

9. Braun A, Muller B, Rosche AA. Population study of the G1691A mutation (R506Q, FV Leiden) in the human factor $\mathrm{V}$ gene that is associated with resistance to activated protein C. Hum Genet. 1996 Feb;97(2):263-4.

10. Gerhardt A, Scharf RE, Beckmann MW, Struve S, 
Bender HG, Pillny M, et al. Prothrombin and factor V mutations in women with a history of thrombosis during pregnancy and the puerperium. N Engl J Med. 2000 Feb 10;342(6):374- 80.

11. Decousus, H., Quere, I., Presles, E., Becker, F., Barrellier, M.T., Chanut, M., et al. (2010a) Superficial venou thrombosis and venous thromboembolism: alarge, prospective epidemiologic study. Annals ofInternal Medicine, 152, 218-224.

12. Martinelli I: Risk factors for venous thromboembolism. Thromb Haemost 2001;86:395-403

13. Akar N, Akar E, Akçay R, Avcu F, Yalcin A, Cin S. Effect of methylenetetrahydrofolate reductase 677 C-T, 1298 A-C, and 1317 T-C on factor V 1691 mutation in Turkish deep vein thrombosis patients. Thromb Res 2000; 97 : 163-7

14. Fodinger $\mathrm{M}$, Horl WH, Sunder-Plassman G. Molecular biology of 5,10- methylenetetrahydrofolate reductase. J Nephrol, 2000;13(1):20-33.

15. Alkanlı. N Iskemik inmeli hastalrda calca, MTHFR gen polimorfizmleri ile plazma total homosistein düzeylerinin araştırılması 2014.

16. Kaya H, Karkucak M, Salifoğlu H, Torun D, Kozan S, Tunca Y. Venöz tromboembolili hastalarda anjiotensin dönüş- türücü enzim I/D ve plazminojen aktivatör-1 4G/5G gen polimorfizmlerinin araştırılması. Tuberk Toraks 2013; 61: 88-95.

17. Rallidis LS, Megalou AA, Papageorgakis NH, Trikas AG, Chatzidimitriou GI, Tsitouris GK. Plasminogen activator inhibitor 1 is elevated in the children of men with premature myocardial infarction. Thromb Haemost 1996; 76: 417- 21.

18. Huber K. Plasminogen activator inhibitor type-1: basic mechanisms, regulation, and role for thromboembolic disease. J Thromb Thrombolysis 2001; 11: 183-93.

19. Seguí $R$, Estellés $A$, Mira $Y$, España $F$, Villa $P$, Falcó $C$, et al. PAl-1 promoter $4 \mathrm{G} / 5 \mathrm{G}$ genotype as an additional risk factor for venous thrombosis in subjects with genetic thrombophilic defects. Br J Haematol 2000; 111: 122-8.

20. Tsantes AE, Nikolopoulos GK, Bagos PG, Rapti E, Mantzios G, Kapsimali V, et al. Association between the plasminogen activator inhibitor-1 4G/5G polymorphism and venous thrombosis. A metaanalysis. Thromb Haemost 2007; 97: 907-13.

21. Martinelli I, Sacchi E, Landi G, Taioli E, DucaF, Mannucci PM: High risk of cerebral-veinthrombosis in carriers of TTTTT a prothrombin genemutation and in users of oral contraceptives. NEngl J Med 1998; 338:1793-7

22. De Stefano, V., Za, T., Rossi, E., Vannucchi, A.M., Ruggeri, M., Elli, E., et al. T. (2008) Recurrent thrombosis in patients with polycythemia vera and essential thrombocythemia: incidence, risk factors, and effect of treatments. Haematologica, 93, 372-380.

23. De Stefano, V., Teofili, L., Leone, G. \& Michiels, J.J. (1997) Spontaneous erythroid colony formationas the clue to an underlying myeloproliferative disorder in patients with Budd-Chiarisyndrome or portal vein thrombosis. Seminars in Thrombosis and Hemostasis, 23, 411-418.

24. de Bruijn, S.F., Stam, J., Koopman, M.M. \& Vandenbroucke, J.P. (1998a) Case-control study ofrisk of cerebral sinus thrombosis in oral contraceptiveusers and in [correction of who are] carriersof hereditary prothrombotic conditions. The Cerebral Venous Sinus Thrombosis StudyGroup. British Medical Journal, 316, 589-592.

25. Janssen, M.C.H., den Heijer, M., Cruysberg, J.R.M., Wollersheim, H. \& Bredie, S.J.H. (2005) Retinal vein occlusion: a form of venous thrombosis or a complication of atherosclerosis? Ameta-analysis of thrombophilic factors. Thrombosis\& Haemostasis, 93, 1021-1026.

26. Hoekstra, J., Bresser, E.L., Smalberg, J.H., Spaander, M.C., Leebeek, F.W. \& Janssen, H.L. (2011) Long-term follow-up of patients with portal veinthrombosis and myeloproliferative neoplasms. Journal of Thrombosis and Haemostasis, 9, 2208-2214.

27. Darwish Murad, S., Plessier, A., Hernandez-Guerra, M., Fabris, F., Eapen, C.E., Bahr, M.J., et al. (2009) Etiology, management, and outcome of the Budd-Chiari syndrome. Annals of InternalMedicine, 151, 167-175.

28. Kumar, S., Sarr, M.G. \& Kamath, P.S. (2001) Mesentericvenous thrombosis. New England Journalof Medicine, 345, 1683-1688.

29. Valla, D.-C., Condat, B. \& Lebrec, D. (2002) Spectrum of portal vein thrombosis in the West.Journal of Gastroenterology and Hepatology, 17(Suppl. 3), S224S227.

30. Hayreh, S.S., Zimmerman, M.B. \& Podhajsky, P. (1994) Incidence of various types of retinal veinocclusion and their recurrence and demographiccharacteristics. American Journal of Ophthalmology,117, 429- 441. 
Tablo 1. Çalışmaya alınan hastaların demografik bulguları

\begin{tabular}{lcccc}
\hline & \multicolumn{2}{c}{ CINSIYET } & \multicolumn{2}{c}{ TOPLAM } \\
\cline { 2 - 5 } PARAMETRELER & KADIN & ERKEK & $\%(100)$ & N(50) \\
\hline 40 YAŞ ÜSTÜ & 7 & 5 & $\% 24$ & 12 \\
\hline 40 YAŞALTI & 25 & 13 & $\% 76$ & 50 \\
\hline & 32 & 18 & $\% 100$ & 38 \\
\cline { 2 - 5 } TOPLAM & $\% 64$ & $\% 36$ & $35.22 \pm 13.56$ \\
\hline YAŞ ORTALAMASI & $34.78 \pm 14.34$ & $36 \pm 12.41$ & & \\
\hline
\end{tabular}

Tablo 2. Hastaların tanılarına göre dağılımı

\begin{tabular}{|c|c|c|c|c|}
\hline Tanı & Kadın & Erkek & & \\
\hline DVT & 8 & 2 & 10 & $\% 20$ \\
\hline Hepatik VT & 3 & 2 & 5 & $\% 10$ \\
\hline Juguler VT & 1 & 0 & 1 & $\% 2$ \\
\hline Mezenter VT & 2 & 0 & 2 & $\% 4$ \\
\hline Portal-mezenter VT & 0 & 2 & 2 & $\% 4$ \\
\hline Portal VT & 4 & 3 & 7 & $\% 14$ \\
\hline$\overline{\text { PTE }}$ & 4 & 0 & 4 & $\% 8$ \\
\hline Retinal VT-İskemik inme & 1 & 1 & 2 & $\% 4$ \\
\hline Retinal VT & 2 & 3 & 5 & $\% 10$ \\
\hline İskemik inme & 2 & 3 & 5 & $\% 10$ \\
\hline$\overline{\text { Sinus VT }}$ & 3 & 1 & 4 & $\% 8$ \\
\hline Splenik VT & 1 & 0 & 1 & $\% 2$ \\
\hline Üst extremite VT & 0 & 1 & 1 & $\% 2$ \\
\hline VKI Tromboz & 1 & 0 & 1 & $\% 2$ \\
\hline Total & 32 & 18 & $\mathrm{~N}(50)$ & $\%(100)$ \\
\hline
\end{tabular}

DVT: Derin ven trombozu, VT: Ven trombozu, PTE: Pulmoner trombo emboli, VCI: Vena kava inferiyor 
Tablo 3. Saptanan etyolojik risk faktörlerinin sayısal dağılımı

\begin{tabular}{|c|c|c|}
\hline RISK FAKTÖRLERI & Sayı & $\%$ \\
\hline MTHFR C677T HOMOZIGOT & 8 & $\% 16$ \\
\hline MTHFR C677T HETEROZIGOT & 4 & $\% 8$ \\
\hline MTHFR A1298C HOMOZIGOT & 8 & $\% 16$ \\
\hline MTHFR A1298C HETEROZIGOT & 12 & $\% 24$ \\
\hline MTHFR A1298C/C677T & 6 & $\% 12$ \\
\hline \multicolumn{3}{|l|}{ HETEROZIGOT BIRLIKTELIĞI } \\
\hline ESANSIYEL TROMBOSITOZ & 7 & $\% 14$ \\
\hline OKS KULLANIMI & 7 & $\% 14$ \\
\hline CERRAHI & 6 & $\% 12$ \\
\hline$\overline{\text { GEBELIK }}$ & 2 & $\% 4$ \\
\hline FAK-V LEIDEN MUTASYONU & 3 & $\% 6$ \\
\hline ANTITROMBIN 3 EKSIKLIĞI & 2 & $\% 4$ \\
\hline PROTEIN S EKSIKLIĞI & 1 & $\% 2$ \\
\hline PAI-1(4G/5G) GEN POLIMORFIZMI & 5 & $\% 10$ \\
\hline PROTROMBIN GEN MUTASYONU & 2 & $\% 4$ \\
\hline HIPERTANSIYON & 2 & $\% 4$ \\
\hline LUPUS ANTIKOAGULANI & 2 & $\% 4$ \\
\hline JAK2 MUTASYONU & 4 & $\% 8$ \\
\hline FIBRINOJEN & 1 & $\% 2$ \\
\hline ANTIFOSFOLIPID ANTIKORLARI & 2 & $\% 4$ \\
\hline IMMOBILIZASYON & 1 & $\% 2$ \\
\hline$\overline{\mathrm{SLE}}$ & 1 & $\% 2$ \\
\hline $\begin{array}{l}\text { TALASEMI MAJOR } \\
\end{array}$ & 1 & $\% 2$ \\
\hline SJÖGREN SENDROMU & 1 & $\% 2$ \\
\hline MALIGNITE & 1 & $\% 2$ \\
\hline IDIYOPATIK & 6 & $\% 12$ \\
\hline BIRDEN FAZLA RISK FAKTÖRÜ & 31 & $\% 62$ \\
\hline
\end{tabular}

